\title{
TEAR FUNCTION AND OCULAR SURFACE CHANGES IN DIABETIC PATIENTS
}

\author{
Magda Salaheldin Abdelaziz, Boshra Mohamed A. EI - Bayoumi* \\ and Iman M. A. Zaki**
}

Department of ophthalmology, Faculty of Medicine. Cairo University

Department of ophthalmology, Memorial Institute for Ophthalmic Research*

and Department of pathology, Research Institute of Ophthalmology**

\section{INTRODUCTION}

Diabetes mellitus (DM) is a multisystem disease that can affect the eyes in many ways. A number of ocular complications have been reported to be associated with DM, many of which can lead to blindness (Goebbels, 2000). Although ocular complications such as chronic inflammation of the lids, orbital infections, cataract, diabetic papillopathy, and diabetic retinopathy have been recognized and studied extensively, the studies on corneal and conjunctival complications of diabetes are still few (Dabbs and Meredith, 1991).

Many diabetic patients complain of dry eye symptoms, such as burning and foreign body sensation. Thus the question as to whether DM is correlated with tear film anomalies or there is a primary surface disease or metabolic alternations of the conjunctival or corneal epithelial cells, independent of the tear film anomalies (Goebbels, 2000).

Schultz et al. (1981) reported that, $47 \%$ to $64 \%$ of diabetic patients have corneal lesions during their life time as epithelial fragility, superficial punctate keratorathy, persistent epithelial defects, and recurrent comeal erosions (Schultz et al, 1981). Different studies have reported structural, metabolic, and functional abnormalities in the conjunctiva and cornea of diabetic patients, and have suggested that these abnormalities may be responsible for the clinical corneal manifestations of DM (Taylor and Kimsey, 1981; Friend et al., 1982; Azar et al., 1989; Tsubota et al, 1991). The tear film has been reported to be unstable and to have higher osmolarity in diabetics (Seifart and Strempel, 1994). Other study also demonstrated 
decreased Schirmer test readings and pronounced signs of conjunctival squamous metaplasia in patients with insulin dependent DM (Goebbels, 2000). How these ocular surface disorders and tear film changes related to clinical parameters of DM, are still controversial.

The aim of this work is to study ocular surface disorders in diabetic patients by performing Schirmmer test, tear break up time test (BUT), and conjunctival impression cytology analysis. The results arc studied and correlated with different clinical parameters of DM; the results are also compared with those of healthy controls.

\section{MATERIAL. AND METHODS}

Thirty-six cyes of 20 diabelic patients were included in this study. There were eight females and twelve males. Their ages ranged between 37 and 67 years with a mean of 56 years \pm 8.299 .

Twenty eyes in 10 normal controls. in whom DM was excluded, were included in this study. There were four females and six males. Their ages ranged between 34 and 65 years with a mean of 51.6 years \pm 11.539 .

All the patients and controls were inpatients in the ophthalmological department, Kasr El - Aini Hospitals. Both groups (patients and controls) were similar regarding age and sex characteristics. The presence of DM in diabetic patients had been confirmed by the internal medicine department. DM was excluded in the controls by the absence of a history of DM and this was confirmed by blood glucose level in blood.

In diabetic patients, the duration of diabetes, the type of diabetes, and blood glucose levels wcre recorded.

Exclusion criteria for both patients and controls were :

${ }^{\circ}$ External cye disease (other than dry eye) or previous ocular surgery.

- Topical medications especially antiglaucoma medications within the past six months.

- Contact lens wear.

- Systemic discases (other than DM in the diabetic group).

All the participants in this study were subjected to full ophthalmological examination which included : measurement of the best corrected visual acuity, slit lamp examination with particular attention to tarsal and bulbar conjunctiva and the cornea. Fundus examination was done and the level of diabetic retinopathy was assessed in diabelic patients. Fluorescien fundus angiography was done whenever indicated. 
Tear break up time tesL (BUT), was performed for all the participants. Fluorescien strips were introduced into the conjunctival sac with minimal stimulation. The participants were instructed to blink several times to ensure adequate mixing of fluorescien. The stained tear film is then scanned with cobalt-blue light of the slit lamp. The interval between the last blink and the appearance of the first corneal black spot in the stained tear film was measured three times, and the mean value of the measurements was calculated. A BUT value of less than 10 seconds was considered abnormal.

Schimer test without anesthesia was done for all participants in this study. A standardized Schirmer paper strip was placed in the lateral canthus and left in place for five minutes. Readings were reported in millimeters of wetting for five minutes. A reading of less than five millimeters was considered abnomal (dry eye).

\section{Conjunctival impression cytology :}

After administration of topical anesthesia, sheets of cellulose acetate filter paper (milipore, HAW 304), were precut into $5 \times 5 \mathrm{~mm}$ pieces with a pointed tip on onc coner, and was applied to the temporal, nasal. and inferior conjunctiva tangential to the limbus with a toothed forceps. Gentle pressure with a glass rod was done for few seconds to ensure close contact of the paper with the conjunctiva. The paper was then removed by gripping the edge and peeling over the examined part of the conjunctiva.

The filter paper was then immersed in a fixative solution containing glacial acetic acid : $37 \%$ formaldehyde : $70 \%$ ethyl alcohol $(1: 1: 20)$ volume ratio for 15 minutes. The filter paper was then subjected for Hematoxylin and Eosin ( $H$ \& E) stain. The specimens were then examined by the light microscope.

The patients were scored into six stages according to Tseng classification (1985) which stated the following:

\section{Stage (0) :}

Normal conjunctival epithelium, moderate number of goblet cells scattered among uniform non-goblet cpithelial cells with nucleus / cytoplasm $(\mathrm{N} / \mathrm{C})$ ratio of $1: 1$.

\section{Stage (1) :}

Early loss of goblet cclls without keratinization, with mild enlargement of nongoblet epithulial cells with $\mathrm{N} / \mathrm{C}$ ratio of $1: 2$ to $1: 3$. 
Stage (2) :

Total loss of goblet cells without keratinization, no goblet cells observed, all epithelial cells are modcrately enlarged and flattened (squamoid) with $\mathrm{N} / \mathrm{C}$ ratio of $1: 4$.

\section{Stage (3) :}

Early and mild keratinization, all epilhclial cclls are markedly squamoid with metachromatic changes in the cytoplasm. Some epithelial cells contained visible keratin filaments. $\mathrm{N} / \mathrm{C}$ ratio is $1: 6$ due to flattening of the cytoplasm and mild pyknotic changes of the nucleus.

\section{Stage (4) :}

Moderate keratinization in the midst of squamoid and metachromatic large epithelial cells, more cells contained densely packed nuclei with $\mathrm{N} / \mathrm{C}$ ratio of $1: 8$.

\section{Stage (5) :}

Advanced keratinization, more keratinized cells with shrunken cytoplasm and densely packed keratin filaments, in which the nuclei are markedly pyknotic, lytic, and sometimes aggregated into keratinized debris. (Tseng, 1985).

The presence of snack-like chromatin (SLC) in the nuclei of conjunctival cells was also studied.

\section{Conjunctival biopsy :}

Some of the participants in this study, were scheduled for cataract extraction surgery, in those cascs, conjunctival biopsy was taken. An area of bulbar conjunctiva $(3 \times 3 \mathrm{~mm}$.) in the inferotemporal quadrant, $5 \mathrm{~mm}$. from the limbus was excised. The specimens were processed to obtain paraffin blocks. Sections of $4 \mathrm{~mm}$ thickness were stained with $H \& E$ stain. The specimens were examined by the light microscope.

\section{Statistical analysis :}

Data wcre collected and analyzed in both patients and controls. 


\section{RESULTS}

Thirty-six cyes of 20 patients with diabetes mellitus were included in this study. There were eight females and twelve males. Their ages ranged between 37 and 73 years with a mean of 56 years \pm 8.299 .

Twenty eyes of 10 non-diabetic patients were included as controls in this study. There were four females and six males. Their ages ranged between 34 and 65 years with a mean of 51.6 years \pm 11.539 .

There were no age or sex related statistical differences between diabetic patients and controls.

Table 1 : Schirmer test and BUT test in patients and controls.

\begin{tabular}{|c|c|c|}
\hline Test & Patients (No. = 36 eyes) & Controls (No. =20 eyes) \\
\hline Schirmer test (mm) & $12.444 \pm 2.144$ & $14.2 \pm 1.056$ \\
\hline BUT test (seconds) & $13.388 \pm 1.201$ & $13.9 \pm 1.333$ \\
\hline
\end{tabular}

Table 2 : Schirmer test and BUT test in diabetic patients [20 patients (36 eyes)] in relation to different clinical parameters of diabetes mellitus.

\begin{tabular}{|c|c|c|}
\hline Clinical parameters & Schirmer test (mm) & BUT test (seconds) \\
\hline Stage of retinopathy: & & \\
Background (26 eyes) & $12.5 \pm 2.453$ & $13.307 \pm 1.225$ \\
Proliferative (10 eyes) & $12.3 \pm 1.059$ & $13.7 \pm 1.251$ \\
\hline Duration of diabetes : & $13 \pm 2.717$ & $13 \pm 0.96$ \\
Less than 10 years (8 patients) & $12.09 \pm 1.654$ & $13.545 \pm 1.335$ \\
10 years or more (12 patients) & & \\
\hline Control of diabetes: & $11.666 \pm 2.933$ & $13.583 \pm 1.443$ \\
Controlled (8 patients) & $12.833 \pm 1.551$ & $13.208 \pm 1.102$ \\
Uncontrolled (12 patients) & & \\
\hline
\end{tabular}

The mean break up time (BUT) test value in diabetic patients was $13.388 \pm$ 1.201 seconds, compared to $13.9 \pm 1.333$ seconds in the control subjects. The differcnce was not statistically significant (table 1 ).

The mean Schirmer test value was $12.444 \pm 2.144 \mathrm{~mm}$ in diabetic paticnts, compared to $14.2 \pm 2.144 \mathrm{~mm}$ in the control group. The mean value in diabetic 
patients was less than that of the controls, but the difference is not statistically significant.

The mean values of BUT test and Schirmer test in diabetic patients were compared according to the level of diabctic retinopathy, duration and control of diabetes. The difference was not statistically significant in all these parameters (table 2 ).

The duration of diabetes in the diabetic group, ranged between two years and twenty years with a mean of 9.15 years \pm 5.544 . The duration of diabetes was 10 years or more in 12 patients $(60 \%)$.

Diabetes was controlled in eight patients (40\%); fasting blood sugar was 180 $\mathrm{mg} \%$ or less in these patients.

Three patients $(15 \%)$ were insulin dependent. and the rest of the patients were on oral hypoglycemic drugs.

26 cyes $(72.2 \%)$, had non proliferative diabetic retinopathy, and 10 eyes $(27.8 \%)$ had proliferative diabetic retinopathy changes.

12 diabetic paticnts $(60 \%)$ reported symptoms of eye fatigue, irritation, and foreign body sensation in onc or both eyes. Three subjects from the control group (30\%) reported similar symptoms. Slit lamp examination, rcvealed absence of signs of dry eye in all participants. Slit lamp examination of the cyelid margin, conjunctiva, and cornea did not reveal any abnormality in both patients and controls.

Conjunctival impression cytology analysis was studied in diabetic patients and healthy controls. The specimens contained conjunctival epithelial cells, and variable amounts of goblet cclls. The specimens were scored into six stages according to Tseng classification in 1985 (plate 1).

In diabetic patients, there were more frequent and more pronounced signs of squamous metaplasia than those of the healthy controls. The difference was of high statistical significance. $33.3 \%$ of the eyes in diabetic paticnts were scored as stage (4), the eyes in the control group did not reach stage (4) (table 3).

Table 3 : The number of eyes according to the stages of squamous metaplasia in diabetic patients and in controls.

\begin{tabular}{|c|c|c|c|c|c|c|}
\hline $\begin{array}{c}\text { Stages } \\
\text { Participants }\end{array}$ & Stage (0) & Stage (1) & Stage (2) & Stage (3) & Stage (4) & Stage (5) \\
\hline $\begin{array}{c}\text { Diabetic patients } \\
(36 \text { eyes) }\end{array}$ & $3(8.3 \%)$ & $5(13.9 \%)$ & $5(13.9 \%)$ & $7(19.4 \%)$ & $12(33.3 \%)$ & $4(11.1 \%)$ \\
\hline Controls (20 eyes) & $8(40 \%)$ & $7(35 \%)$ & $4(20 \%)$ & $1(5 \%)$ & $\cdots \cdots--$ & $\ldots \ldots-\cdots$ \\
\hline
\end{tabular}


The slatus of retinopathy, the duration of diabetes and the control of diabetes did not seem to affect the grades of squamous metaplasia.

The prevalence of snake-like chromatin (SLC) in the nuclei of the conjunctival cells was elevated starting from stage (3) up to stage (5).

Conjunctival biopsy confirmed the findings of impression cytology. There were variable grades of morphological changes. These changes ranged from moderate loss of goblet cells up to complete loss of goblet cells with squamous metaplasia (plate 2). These changes were not related to the status of retinopathy, duration or control of diabetes. 

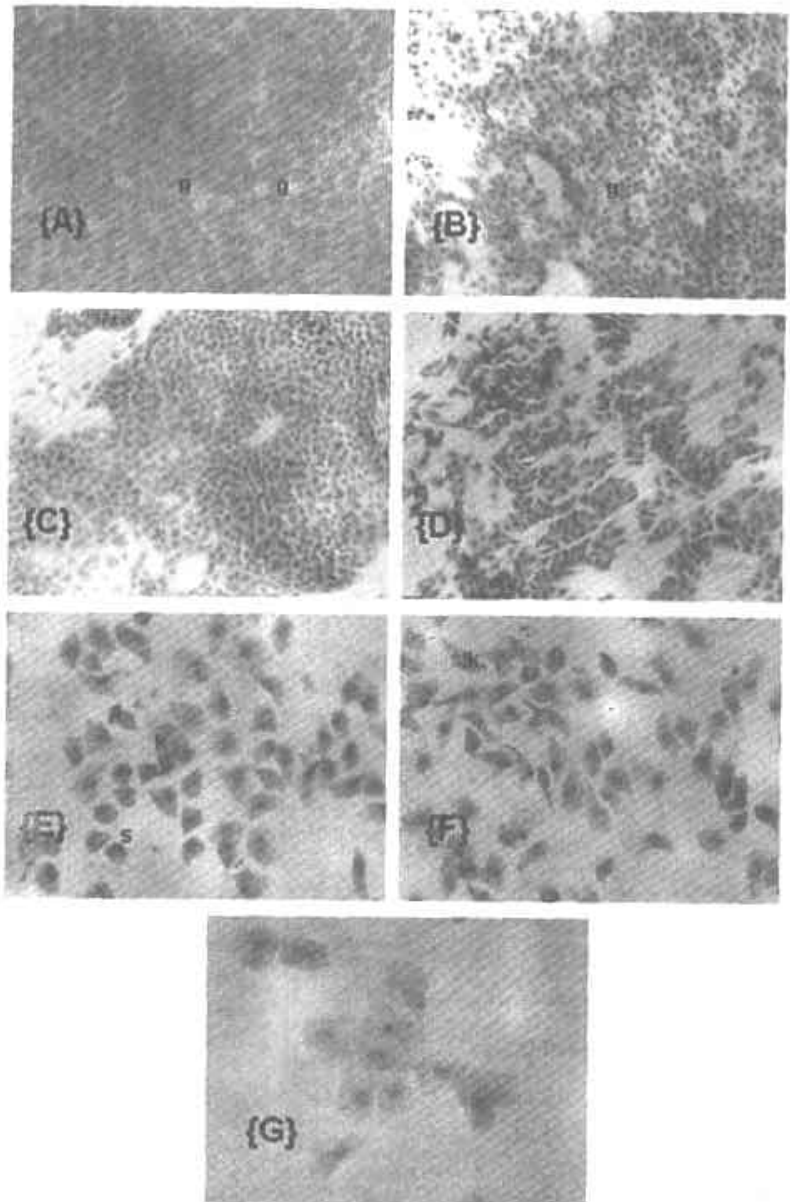

Plate (1) : Light photomicrographs of conjunctival impression cytology. Fig. (1 - A) : A light photomicrograph of nomal conjunctival impression cytology, (Stage 0) showing
moderate number of goblet cells (g).

(H \& E.; x 500)

Fig. (1 - B) :A light photomicrograph of conjunctival impression cytology, (Stage 1) showing early loss of goblet cells $(\mathrm{g})$.

(H \& E:; $x 250)$
Fig. $(1-C): A$ light photomicrograph of conjunctival impression cytology, (Stage 2 ) showing total loss of goblet cells.

(H \& E: $x$ 250)
Fig. (1 - D) : A light photomicrograph of conjunctival impression cytology, (Stage 3) showing mild keratinization, the epithelial cells are markedly squamoid.

(H \& E.; x 250)

Fig. (1 - E) :A light photomicrograph of conjunctival impression cytology, (Stage 4) showing moderate keratinization (k) in the midst of squamoid cells (s). (H \& E.; $x 500$ ) Fig. $(1-F):$ A light photomicrograph of conjunctival impression cytology, (Stage 4) showing moderate keratinization in the midst of squamoid cells with multiple scattered cells with nuclei showing SLC (snake like chromatin).

(H \& E.: $x$ 500)

Fig. (1 - G) :A light photomicrograph of conjunctival impression cytology, (Stage 5) showing markedly keratinized cells with pyknotic nuclei.

(H \& E.; $x$ 500) 

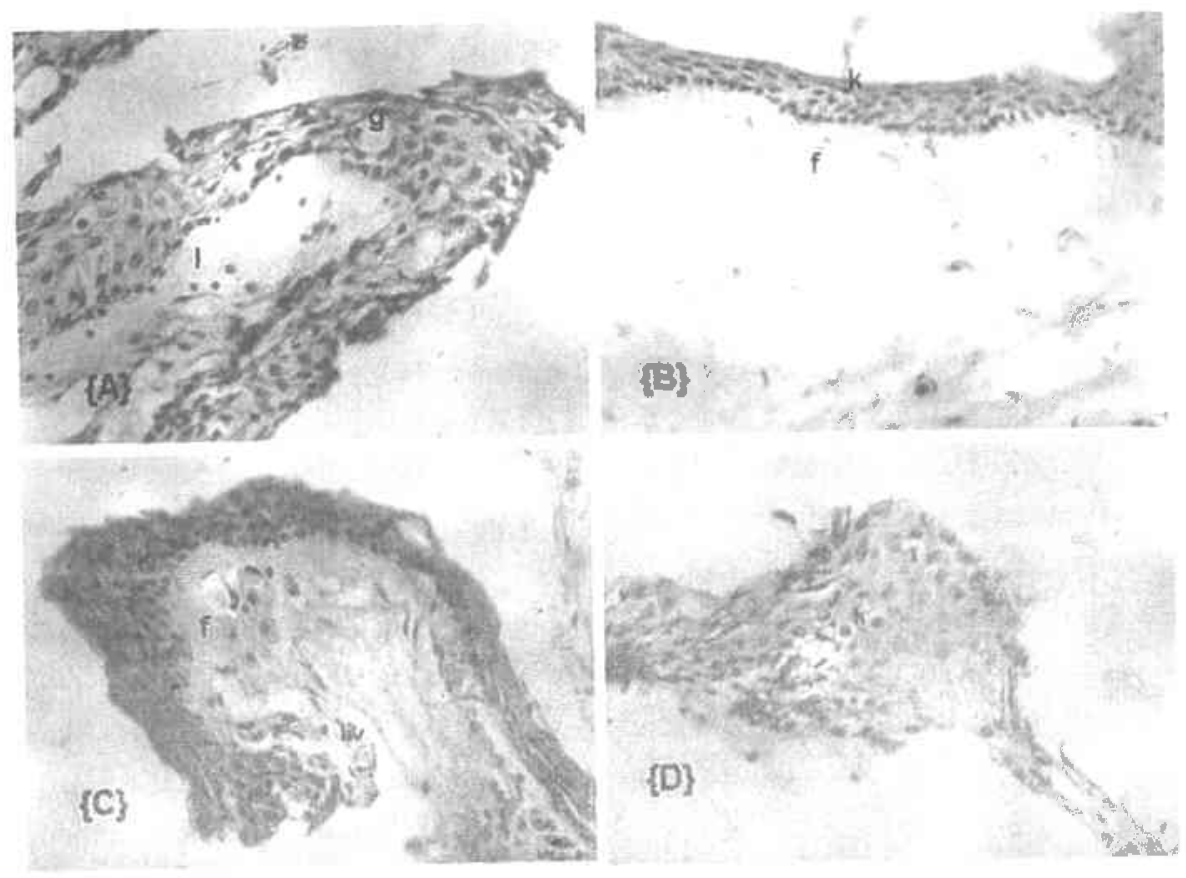

Plate (2) : Lipht plotomicregraphs of conjunctival spithelial issuc.

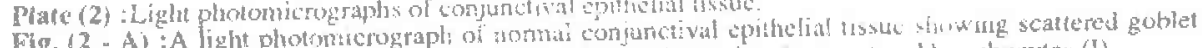

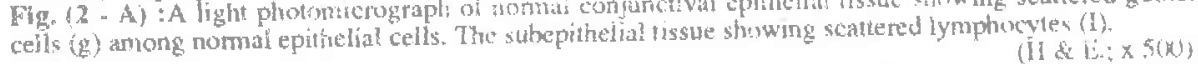

Fig. (2 - 13) :A light photomicrograph of conjunctival epuhelial tissue showing complete loss of goblet cells with moderate keratinization $(k)$. The subepithelial tissue showing mode rate fibroplasia (f) with scatlered lymphocytes.

(H \& E; $\times$ 500)

Fig. (2 - C) :A light photomicrograph of conjuncival epithelial tissue showing complete loss of gobles cells with moderate keratinization $(\mathrm{k}$ ). The subepitholial tissue showing moderate fihropiasia (f) with scattered dilated bloud vessels (bv).

(H \&. E: $\times 500)$

Fig. (2 - D) : A light photomicrograph of conjunctival epithelial tissue with marked keratinization (k).

(H \& E. X 500) 


\section{DISCUSSION}

Several studies have reported structural, metabolic, and functional abnormalities in the conjunctiva and cornea of diabetic patients (Taylor and Kimsey, 1981; Friend et al., 1982; Azar et al., 1989; Tsubota et al., 1991). However, the cause of these alternations is not clear. In addition, the relation between these changes and the clinical parameters of diabetes is still a matter of controversy (Dorgu et al., 2001). The tear film has been reported to be unstable and with high osmolarity in diabeties (Seifart and Strempel, 1994). Another study also demonstratcd decreased Schirmer test readings and pronounced signs of conjunctival squamous metaplasia in patients with insulin dependent diabetes (Goebbels, 2000).

In this study, th readings of the break up time test and Schirmer test were less in diabetic patients than these readings in the controls; however, the difference was not statistically significant. The status of retinopathy, the duration and control of diabetes in the diabetic patjents were not related to the tear function parameters. However, it was reported that tear function parameters showed marked changes in diabetics as compared to controls. Schirmer test values were not related to the duration of diabetes, or the retinopathy status, but were significantly lower in diabetics with poor metabolic control. It was also reported that the results of the break up time test showed marked instability of the tear film in diabetic patients with poor metabolic control (Dorgu et al., 2001). It was suggested that, fluctuations in the glycemic control may affect the lacrimal gland secretory functions (Dorgu et al., 2001). It was also demonstrated that the decreased amount of reflex tearing in diabetics may be the result of diminished corneal and conjunctival sensitivity which has been demonstrated in diabetics by elcctronic aesthesiometry (Draeger, 1984). On the other hand, it was reported that, tear film stability was found to be equivalent in diabetic and non diabetic individuals (Goebbels, 2000). It was also reported that the measurement of the break up time of the tear film is a rough test for the determination of tear film stability. Large interindividual and intraindividual deviations can be found even when performed in a standardized procedure (Norn, 1969; Vanley, 1977). Schirmer test is rather a rough screening test for the detection of tcar hyposecretion than a technique for the precise measurement of tear production. The sensitivity of Schirmer test could be as low as $10 \cdot 30 \%$ (Shaprio and Merin, 1979; Lamberts et al., 1979).

In this study, impression cylology analysis provided evidence that prominent squamous metaplasia and goblet cell loss existed in diabeties compared with control 
subjects, the difference was highly significant. However, these changes were not related to the status of retinopathy. duration or control of diabetes. These results agreed with the results of other studies. It was stated that. there was prominent squamous metaplasia and goblet cell loss in diabetic patients compared to controls. It was also reported that, impression cytology analysis parameters did not relate to the duration of diabetes, and the status of retinopathy. However, these changes were more marked in patients with poor metabolic control, and in patients with peripheral neuropathy (Dorgu et al., 2001). It was also reported that impression cytology of the conjunctival surface showed distinctly more frequent and more pronounced sings of conjunclival metaplasia in diabetic patients (Goebbels, 2000).

Goblet cell counts are known to reflect the health status of the ocular surface. Goblet cell loss is a well-known sign of squamous metaplasia and goes along with an increase of cellular stratification and keratinization (Maumenee, 1979). Loss of goblet cells can lead to shortening of BUT and instability of the tear film as a result of decreased mucin production because goblet cells are the major source of mucin in the tcar film (Tseng et al., 1984). However, it was not clear if the dry eye in diabetics results from mucin deficiency because sources of mucin other than the goblet cells are present and the mucin content was not measured in the tears. Studies on the mucin gene expression of the diabetic ocular surface would provide useful information (Dorgu et al., 2001).

The mechanisms of these ocular surface changes during the course of diabetes are still not clear. However, it was reported that, loss or decrease of trophic effects of trigeminal sensory nerves on the conjunctiva and cornca may be responsible (Judzewitsh et al., 1983; Marfurt and Echtenkamp, 1995). It was also reported that squamous metaplasia of the conjunctival epithelium may account for most, if not all, the clinical morbidity of corncal complications in diabetes. This means that the abnormalities of the ocular surface cpithelium can occur in the absence of tear film abnormalities. Treatment in such a condition would thus be directed towards the epithelium, rather than the tear film (Dorgu et al., 2001). Apart from the conventional dry eyc therapies including artificial tear drops and lubricants. promising approaches using aldose reductase inhibitors like sorbinil and $\mathrm{CT}-112$ have been tested and reported to improve nerve conduction, comeal sensitivity, epithelial discase, and even tear function paramcters (Hosotani, 1995). Topical retinoids were reported to promote the production of new basement membrane components and cellular differentiation, and to maintain cellular growth. Topical retinoids may be promising for the treatment of diabetic conjunctival epithelial diseases (Tseng and 
Farazdaghi, 1988). Impression cytology analysis will help in the decision making to treat such a disease process.

In this study, impression cytology was found to be casy and reliable method to examine the conjunctival epithelium. Conjunctival biopsy done in some cases in this study confirmed the results of the impression cytology analysis.

\section{SUMMARY}

Diabetes mellitus is a multisystem disease that can affect the eye in many ways. Many diabetic patients complain of dry cye symptoms, such as burning and foreign body sensation. Thus the question as to whether DM is corrclated with tear film anomalies or there is a primary surface disease or metabolic alternations of the conjunctival or corneal epithelial cells, independent of the tear film anomalies. This work was done to study ocular surface disorders in diabetic patients by performing Schirmmer test, tcar film break up time test, and conjunctival impression cylology analysis. Diabetic patients showed distinct signs of conjunctival surface disorders as evident by the impression cytology analysis, so diabetic patients are more susceptible to dry cye. However, in this study, the BUT test and Schirmer test were found to be normal.

In conclusion, impression cylology analysis is a non-invasive and reliable technique, and can help in the decision making to treat ocular surface abnormalitics in diabetics. Further clinical and experimental work about changes of tear functions and impression cylologic parameters after introduction of aldose reductase inhibitors or topical retinoids will lead to better understanding and management of diabetic ocular surface diseases.

\section{REFERENCES}

1. Azar, D.T.; Spurr-Michaud, S.J.; Tisdale, A.S. and Gibson, I.K. (1989) : Decreased penetration of anchoring fibrils into the diabetic stroma. A morphometric analysis. Arch Ophthalmol, $107: 1520$ - 1523.

2. Dabbs, G.K. and Meredith, T.A. (1991) : Diabetic eye disease. In Davidson JK (ed.) : Clinical diabetes mellitus: A problem oriented approach. 2nd ed., Thieme Medical Publishers. New York Ch. $26: 427$ - 443.

3. Dorgu, M.; Katakami, C. and Inoue, M. (2001) : Tear function and ocular surface changes in non-insulin dependent diabetes mellitus. Ophthalmology 108 : $586-592$. 
4. Draeger, J. (1984) : Corneal sensitivity. Measurement and clinical importance. Heidelberg: Springer, $58-65$.

5. Friend, J.; Ishii, Y. and Thoft, R.A. (1982) : Corneal epithelial changes in diahetic rats. Ophthalmic Res., $14: 269-278$.

6. Goebbels, M. (2000) : Tear secretion and tear film function in insulin dependent diabctics. Br. J. Ophthalmol. $84: 19-21$.

7. Hosotani, H.; Ohashi, Y.; Yamada, M. and Tsubota, K. (1995) : Reversal of abnormal corneal epithelial cell morphologic characteristics and reduced corneal sensitivity in diabetic patients by aldose reductase inhibitor. CT - 112. Am. J. Ophthalmol, 119 : 288 - 294.

8. Judzewitsh, R.G.; Jaspan, J.B. and Polonsky, K.S. (1983) : Aldose reductase inhibition improves nerve conduction velocily in diabetic patients. N. Engl. J. Med., 308 : $119-125$.

9. Lamberts, D.W.; Foster, G.S. and Perry, D. (1979) : Schirmer test after topical anesthesia and tear meniscus height in normal eyes. Am. J. Ophthalmol. $97: 1082$ -1085 .

10. Manfurt, C.F. and Echtenkamp, S.F. (1995) : The effect of diabetes on neuropeptide content in the rat cornea and iris. Invest. Ophthalmol. Vis. Sci.. $36: 1100$ $-1106$.

11. Maumenee, A.E. (1979) : Keratinization of the conjunctiva. Trans. Am, Ophthalmol. Soc., $77: 1.33-143$.

12. Norn, M.S. (1969) : Desiccation of the precorncal tear film. 1. Corneal wetting time. Acta Ophthalmol., 47: 865 - 869 .

13. Schultz, R.O.; Van Horn, D.L. and Peters, M.A. (1981) : Diabetic keratopathy. Trans. Am. Ophthalmol. Soc., $79: 180$ - 199.

14. Seifart, U. and Stempel, I. (1994) : Trockenes Auge und Diabetes mellitus. Ophthalmologe, 91 : 235 - 239.

15. Shaprio, A. and Merin, S. (1979) : Schirmer test and break up time test of tear film in normal subjects. Am. J. Ophthalmol. $88: 752$ - 757.

16. Taylor, H.R. and Kimsey, K.H. (1981) : Corneal epithelial basement membrane changes in diabetes. Invest. Ophthalmol. Vis. Sci., $20: 548-553$.

17. Tseng, S. (1985) : Staging of conjunctival squamous metaplasia by impression cytology. Ophthalmology, $92: 728-733$.

18. Tseng, S. and Farazdaghi, M. (1988) : Reversal of conjunctival transdifferentiation by topical retinoic acid. Cornca. $7: 273-279$. 
19. Tseng, S.; Hirst, L.W. and Maumenee, A.E. (1984) : Possible mechanisms for the loss of goblet cells in mucin-deficient disorders. Ophthalmology, $91: 545$ 552 .

20. Tsubota, K.; Chiba, K. and Shimazaki, J. (1991) : Comcal epithelium in diabetic patients. Cornea, $10: 156-160$.

21. Vanley, G.T. (1977) : Interpretation of tear film break up. Arch. Ophthalmol., $95: 445-448$. 


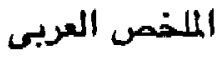

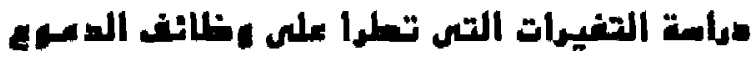 وسطع الهلتحمة عند مرفه صاء السكريل}

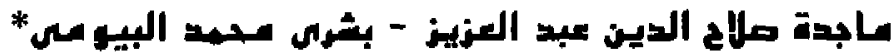

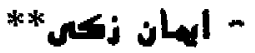

$$
\begin{aligned}
& \text { تسم طب وجراحة العيين - كلية الطب - جامعة القامرة }
\end{aligned}
$$

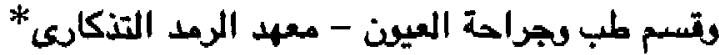

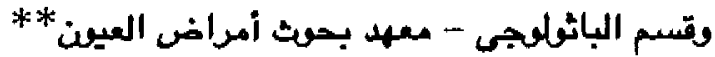

يعتبر مرض داء السكرى من الامراض التى تئزر على جميع اجزاء العين ويؤاى

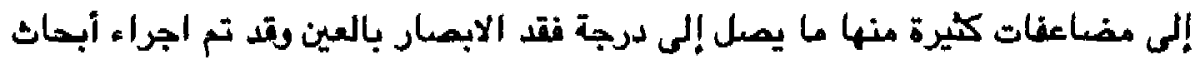
عديدة لدراسة علاقة مرضر داء السكرى بالمياه البيضاء وتغيرات الثبكية ولكن لم تكن الثن

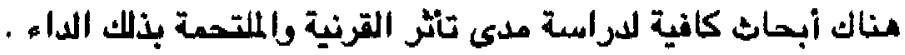

وقد تم اجراء مذا البحث بغرض دراسـة تأثير السكر على ونائف الدموع وسطح

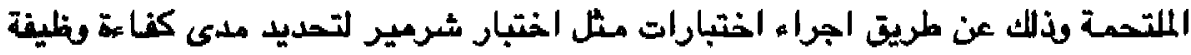

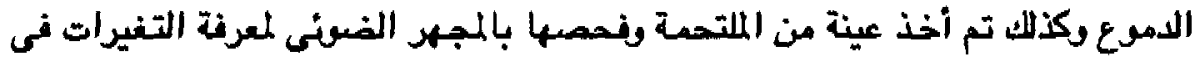

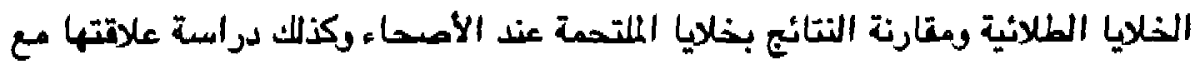
مستوى الجلوكذذ بالدم والمدة الزمنية الليكر وكذلال مع درجة تأثر الشبكية .

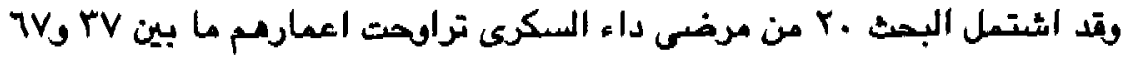

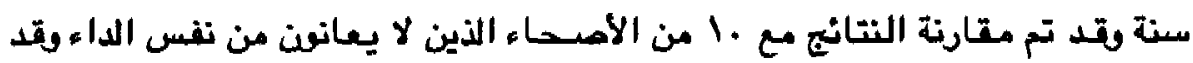

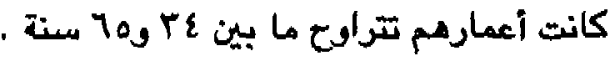


ولقـد تم عمل فحص اكلينيكى للعين لجمـيع المثـاركين فى البحث ويشـمل هـا

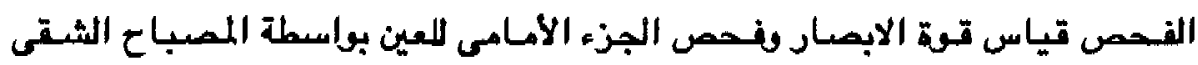

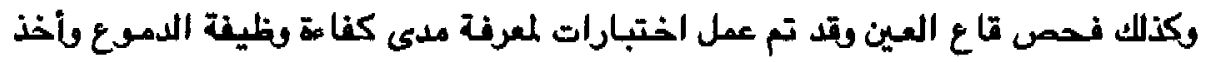

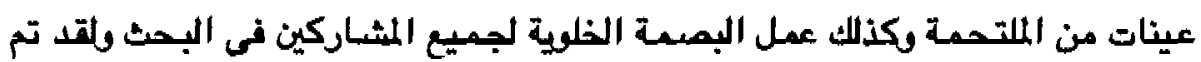
فحص الخلايا الطلائية الملتحمة بواسطة المجهر الضينى .

وكان من نتائج البمث أن وظيفة الدموع لم تختف كيرا فى مرضم داء السكرى

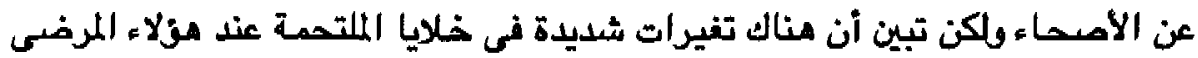
بالمقارنة بالامساء .

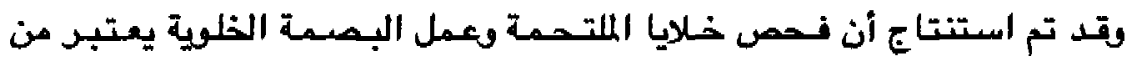

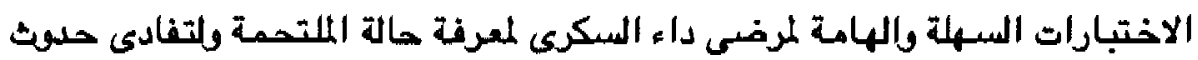

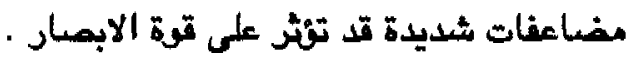

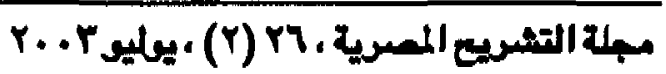

